\title{
RANCANGAN TATA KELOLA TI UNTUK INSTITUSI PEMERINTAH STUDI KASUS BAPPENAS
}

\author{
Risma Bayu Putra dan Dana Indra Sensuse \\ Fakultas Ilmu Komputer, Universitas Indonesia, Depok, Indonesia \\ putra_email07@yahoo.com,dana@cs.ui.ac.id
}

\begin{abstract}
Abstrak
Penerapan tata kelola pemerintahan dan percepatan penerapan teknologi informasi pada pemerintahan membuat institusi-institusi pemerintah harus meningkatkan fungsi teknologi informasinya. Dengan meningkatnya peran teknologi informasi maka investasi di bidang teknologi informasi semakin besar dan semakin kompleks dalam pengelolaannya. Oleh karena itu dibutuhkan suatu tata kelola teknologi informasi yang sesuai dengan kebutuhan masing-masing organisasinya. Bappenas sebagai institusi perencanaan pemerintah merasa perlu untuk memiliki suatu tata kelola teknologi informasi yang baik agar investasi teknologi informasinya dapat berjalan dengan baik. Tulisan ini membahas rancangan suatu tata kelola teknologi informasi untuk Bappenas dengan menggunakan gabungan model tata kelola teknologi informasi diantaranya model Peterson, model Weill \& Ross, model ITGI focus area, model AS 8015 standar Australia, dan kontrol objektif dari COBIT. Dari keseluruhan model tersebut dapat dilihat seberapa jauh tingkat kematangan tata kelola TI pada Bappenas yang kemudian akan ditentukan solusi untuk mencapainya.
\end{abstract}

Kata kunci : BAPPENAS, COBIT, model Peterson, model Weill \& Ross, model ITGI focus area, model AS 8015 standar Australia, tata kelola IT

\section{Latar Belakang}

Teknologi informasi (TI) pada awalnya hanya dimanfaatkan untuk mengautomasi proses-proses manual yang terjadi pada suatu organisasi. Seiring dengan perkembangan jaman dan semakin kompleksnya proses-proses yang harus diautomasi membuat cara pandang dan penerapan TI menjadi berbeda. Fungsi TI mengalami perubahan, tidak lagi hanya untuk mempermudah pada level operasional tetapi mulai digunakan sebagai suatu strategi yang merupakan faktor utama dalam pengambilan keputusan oleh para pimpinan. Karena organisasi mendapatkan manfaat akan pendayagunaan TI, maka investasi TI dirasa perlu untuk meningkatkan kemampuan organisasi tersebut untuk berkompetisi dan memberikan pelayanan yang baik bagi masyarakat.

Kadang kala investasi TI menjadi tidak memiliki nilai bagi organisasi karena tidak adanya koordinasi antar pimpinan, proses yang dilakukan tidak dengan prosedur yang jelas, sumber daya yang ada memiliki kemampuan yang rendah, investasi yang dilakukan tidak sejalan dengan proses bisnis, investasi yang dilakukan tidak mengurangi resiko yang ada pada organisasi [1]. Setiap organisasi tentu berharap investasi TI yang dilakukan akan membawa keuntungan bagi organisasi, melihat begitu pentingnya manfaat investasi TI pada organisasi maka diperlukan suatu penyusunan tata kelola TI yang sesuai dengan tujuan bisnis organisasi tersebut tanpa meninggalkan standar-standar internasional yang berlaku.

Bappenas merupakan institusi perencana pembangunan dan sekaligus sebagai institusi pemikir (think tank) pemerintah. Penyusunan tata kelola TI pada institusi pemerintah harus mengacu pada tujuan dari organisasinya. Oleh karena itu dalam menyusun sebuah tata kelola TI pada Bappenas harus mengacu pada tujuan dari Bappenas sebagai institusi perencana.

Ada beberapa model tata kelola TI yang bisa diterapkan pada Bappenas diantaranya AS 8015, ITGI, Weill \& Ross, Peterson, dan COBIT. Masingmasing model ini memiliki keunggulan pada masingmasing pendekatannya. Selain itu model-model tersebut dapat melihat dengan jelas permasalahan yang terjadi di Bappenas. Oleh karena itu penelitian ini hendak menjawab pertanyaan penelitian "Bagaimana rancangan tata kelola TI yang sesuai dengan institusi pemerintah dengan studi kasus Bappenas?". 


\section{Landasan Teori}

Banyak definisi mengenai tata kelola TI yang telah dikembangkan oleh para peneliti, diantaranya:

IT Governance is the organizational capacity exercised by the board, executive management and IT management to control the formulation and implementation of IT strategy and in this way ensure the fusion of business and IT [2].

IT Governance is the responsibility of the board of directors and executive management. It is an integral part of Enterprise Governance and consists of the leadeship and organizational structures and processes that ensure that the organization's IT sustains and extends the organization's strategies and objectives [1].

IT Governance describes a firm's overall process for sharing decision rights about IT and monitoring the performance of IT investments [3]

IT Governance is the system by which an organization's IT portfolio is directed and controlled. IT Governance describes (a) the distribution of IT decision-making rights and responsibilities among different stakeholders in the organization, and $(b)$ the rules and procedures for making and monitoring decisions on strategic IT concerns [4].

IT Governance defines the locus of enterprise decision-making authority for core IT activities [5].

IT Governance refers to the patterns of authority for key IT activities [6].

IT Governance is the degree to which the authority for making IT decisions is defined and shared among management, and the processes managers in both IT and business organizations apply in setting IT priorities and the allocation of IT resources [7].

IT Governance describes the locus of responsibility for IT function [8].

Weill \& Ross (2004) memberikan pendefinisian tata kelola TI sebagai berikut:

"IT Governance is defined as specifying the decision rights and accountability model to encourage desirable behavior in IT usage".

Berdasarkan penelitian ICT Governance yang dikembangkan Australia yaitu AS8015 (2005) mendefinisikan tata kelola TI:

"The system by which the current and future use of ICT is directed and kontrolled. It involves evaluating and directing the plans for the use of ICT to support the organisation and monitoring this use to achieve plans. It includes the strategy and policies for using ICT within an organisation".

Definisi-definisi IT Governance di atas kemudian disesuaikan dengan kondisi Bappenas. Untuk memfokuskan penelitian ini, penulis mengambil beberapa definisi dari tata kelola TI yang terkait dengan penelitian ini diantaranya IT Governance Institute (2003), Van Grembergen (2004), Weill \& Ross (2004), AS 8015 (2005). dan COBIT (2007).
Walaupun definisi yang ada berbeda pada beberapa aspek, namun mereka fokus pada isu yang sama yaitu bagaimana TI dapat memberikan nilai dengan menyelaraskan hubungan antara TI dan bisnis dan TI dapat mengurangi resiko [1].

\subsection{Struktur, proses dan mekanisme hubungan}

Van Grembergen, De Haes \& Guldentops (2004) serta Peterson (2004) mengemukakan bahwa penerapan tata kelola TI memerlukan kombinasi Struktur, Proses dan Mekanisme Hubungan untuk keduanya (struktur dan proses).

Setiap organisasi pasti akan berbeda satu dengan yang lain dalam penerapan struktur, proses dan mekanisme hubungannya, tergantung dari kondisi, situasi dan tantangan yang dihadapi masing-masing organisasi.

\subsubsection{Struktur}

Dalam hal ini diartikan hal-hal mendasar harus dibangun atau sebagai fondasi agar tata kelola TI dapat berjalan. Struktur mencakup struktur organisasi TI, pembagian peran dan tanggung jawab, CIO on board, IT Steering committee dan IT strategy commitee. Struktur organisasi TI mencakup bagaimana fungsi TI diorganisir, dan dimana otoritas pembuatan keputusan ditempatkan dalam organisasi tersebut. Pembagian peran dan tanggung jawab mengharuskan definisi peran dan tanggung jawab yang jelas dan tidak ambigu untuk board dan manajemen eksekutif, serta sistem pelaporan kinerja bisnis dan kepatuhan (complience). Board dan manajemen menjalankan tugas pengaturan melalui $I T$ strategic commitee dan memastikan bahwa IT merupakan agenda regular dalam kegiatan mereka.

\subsubsection{Proses}

Proses lebih menggambarkan tentang tahapantahapan yang harus dilalui dalam menjalankan suatu proyek TI, dimulai dari pencetusan ide, penterjemahan proyek bisnis berbasis TI, penentuan prioritas proyek, penyusunan anggaran proyek, persetujuan proyek, persetujuan anggaran proyek, pengembangan proyek, operasional proyek hingga pemeliharaan proyek. Dalam pelaksanaannya, ada beberapa tools yang digunakan sebagai acuan untuk membuat suatu model tata kelola TI sehingga proses yang dilakukan dapat berjalan dengan baik, yaitu: Strategic Information System Planning, policy dan procedure, Information Economics, IT Balance Score Card, Service Level Agreement, COBIT and ITIL, IT Alignment/Governance Maturity model. 


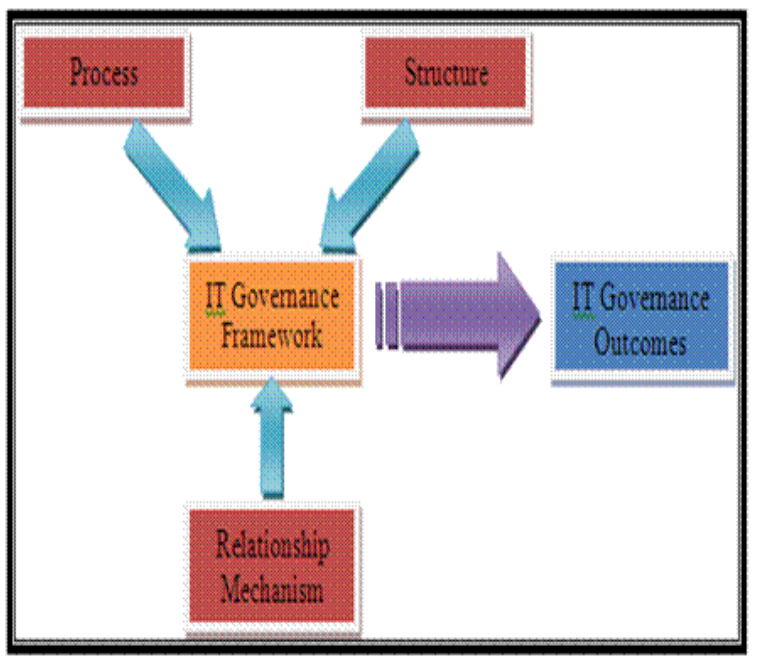

Gambar 1. Peterson model (2001)

\subsubsection{Mekanisme Hubungan}

Selain dua hal diatas yaitu Struktur dan Proses, ternyata hal yang ketiga yaitu mekanisme hubungan disadari tidak kalah penting mengambil bagian dalam penerapan tata kelola TI. Hal ini mengingat meskipun struktur dan proses baik bukan jaminan akan pencapaian tata kelola TI, namun harus ditunjang dengan saling pengertian antara TI dengan bisnis unit lain atau dengan kata lain komunikasi. Untuk mencapai tata kelola TI yang efektif diperlukan komunikasi dua arah, partisipasi yang baik dan hubungan kolaborasi antara orang-orang bisnis dan orang-orang TI. Sangat krusial sekali untuk memfasilitasi sharing, knowledge management, continous education dan cross training. Mekanisme hubungan juga dapat dicapai melalui partisipasi aktif dan kolaborasi antar Stakeholder, rewards dan incentive, business/ IT co-location, cross functional business/IT training dan rotasi. Secara hierarki dapat digambarkan hubungan Struktur, Proses dan mekanisme hubungan pada Gambar 1.

\subsection{Model Weill-Ross}

Weill \& Ross (2004) berpendapat bahwa:

"IT Governance is defined as specifying the decision rights and accountability model to encourage desirable behavior in IT usage".

Menurut Weill \& Ross (2004) bahwa tata kelola TI yang efektif perlu menyelesaikan atau menjawab tiga pertanyaan yaitu:

1. What - Keputusan apa yang harus dibuat untuk memastikan pengelolaan dan penggunaan IT yang efektif?

2. Who - Siapa yang perlu membuat keputusan tersebut?

3. How - Bagaimanakah keputusan tersebut dibuat dan dimonitor?

Untuk menjawab pertanyaan pertama dan kedua yaitu keputusan apa yang perlu dibuat? Dan siapa yang membuatnya? Maka bagaimana keputusan tersebut dibuat dan dimonitor dapat dilihat pada Tabel 1 .

Tabel 1. Governance Arrangements Matrix (Weill \& Ross, 2004)

\begin{tabular}{|l|l|l|l|l|l|l|l|l|l|l|l|}
\hline \multirow{2}{*}{ What } \\
Who
\end{tabular}


Pada kolom mendatar (horizontal) kita dapat melihat lima keputusan penting yang perlu dibuat yakni:

1. IT Principles, merupakan suatu pernyataan top level manajemen tentang bagaimana TI digunakan dalam bisnis organisasi.

2. IT Architecture, mendefinisikan integrasi dan standardisasi dalam sistem.

3. IT Infrastructure, menentukan layanan yang digunakan bersama (shared services)

4. Business Application Needs, menentukan pemenuhan kebutuhan aplikasi bisnis dengan membangun aplikasi bisnis yang perlu diadakan atau dikembangkan oleh TI.

5. IT Investment and Prioritization, seringkali ditulis dengan IT Investment saja, ini adalah keputusan-keputusan yang terkait dengan inisiatif mana yang perlu diprioritaskan dan berapa banyak yang perlu dikeluarkan.

Kelima dasar yang dikembangkan oleh Weill \& Ross (2004) ini sangat penting dipahami oleh petinggi-petinggi organisasi agar dapat menjadi bagian dari good corporate governance.

Tata kelola pemerintahan dengan memanfaatkan teknologi informasi atau yang sering kita sebut sebagai e-government perlu melihat ini. Proyek $e$ government di berbagai daerah masih sering terjadi pemborosan dan tidak berguna, hal ini karena belum dipahami tentang pengembangan teknologi informasi dan belum adanya alat kendali baik oleh eksekutif maupun inspektorat jendral.

Keputusan-keputusan tersebut bukan keputusan yang independen melainkan adalah sesuatu yang saling terhubung. Hubungan yang umum terlihat adalah mengalir dari kiri ke kanan. Sedangkan pada baris mendatar (vertical) kita melihat enam archetype pengambil keputusan yaitu sebagai berikut:

1. Business Monarchy yaitu jajaran Direksi dan Komisaris.

2. IT Monarchy yaitu jajaran manajemen TI.

3. Feudal yaitu setiap divisi atau unit bisnis membuat keputusan sendiri secara independen

4. Federal yaitu kombinasi antara kantor pusat (corporate center) dengan unit bisnis dengan atau tanpa keterlibatan TI

5. IT duopoly yaitu TI dan salah satu antara top manajemen atau pemimpin unit bisnis

6. Anarchy yaitu pengambilan keputusan secara independen oleh individual atau kelompokkelompok kecil.

Setelah diketahui siapa dan apa kemudian ditentukan isi dari koordinat pertemuan apa dan siapa yang diisi pada kolom How (Input, Decision). Dari penelitian yang dilaksanakan oleh Weill \&
Ross pada 2004 perusahaan di 23 negara, maka ada tiga mekanisme tata kelola TI yang efektif:

1. Struktur dalam pengambilan keputusan

Merupakan suatu proses yang akan menggambarkan hak dan tanggung jawab setiap unit kerja dalam organisasi untuk mengajukan suatu ide proyek, melihat keterlibatan unit kerja dalam mengajukan ide pada suatu proyek dan melihat siapa yang berhak memutuskan suatu proyek berbasis TI.

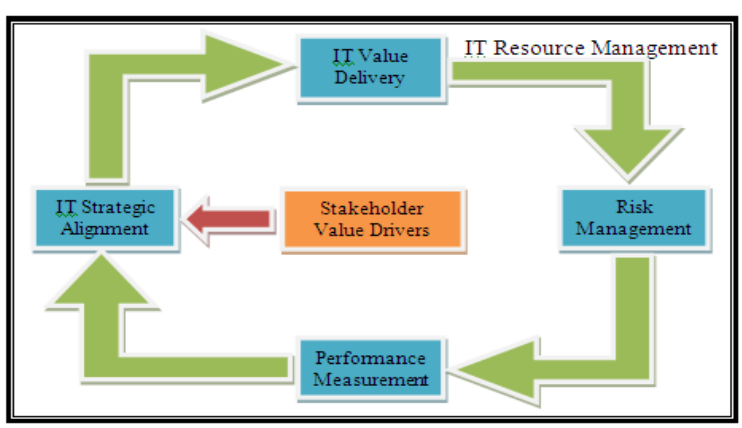

Gambar 2. Area Fokus Model ITGI [1]

2. Proses keselarasan

Bagaimana menciptakan keselarasan antara bisnis dan TI, sehingga investasi yang dikeluarkan untuk proyek bisnis berbasis TI dapat memberikan manfaat yang maksimal untuk memajukan bisnis

3. Pendekatan komunikasi

Merupakan cara untuk menimbulkan kesadaran pentingnya tata kelola TI yang baik bagi organisasi. Pendekatan yang diambil dapat berupa pengumuman, pendidikan dan pelatihan tentang prinsip-prinsip dan kebijakan tata kelola TI serta pemberitahuan bagaimana proses pengambilan keputusan TI di organisasi.

\subsection{Model ITGI Focus Area}

"IT Governance is the responsibility of the board of Directors and executive management. It is an integral part of enterprise governance and consists of the leadership and organizational structures and processes that ensure that the organization's IT sustain and extends the organization's strategy and objectives" [1]. IT Governance Institute memberikan fokus pada dua hal, yaitu:

1. Bagaimana TI memberikan nilai tambah bagi bisnis. Hal ini dapat dipicu oleh keselarasan strategis antara bisnis dan TI.

2. Penanganan resiko pada implementasi TI. Hal ini dipengaruhi oleh prinsip akuntabilitas suatu organisasi. 
Kedua faktor di atas harus didukung oleh sumber daya yang memadai dan harus memiliki ukuran untuk menjamin bahwa hasil yang diinginkan telah diperoleh. Ada lima domain utama tata kelola TI menurut ITGI, meliputi strategic alignment of IT with business, value delivery of IT, management of IT risks, IT resource management, dan performance measurement of IT.

\subsection{Model AS-8015}

AS 8015 (2005) merupakan model Australia dalam The corporate Governance of information and Communication Technology, yang baru dikeluarkan di tahun 2005 ini. Model ini mencakup standar-standar dalam proyek dan operasi ICT di Australia.

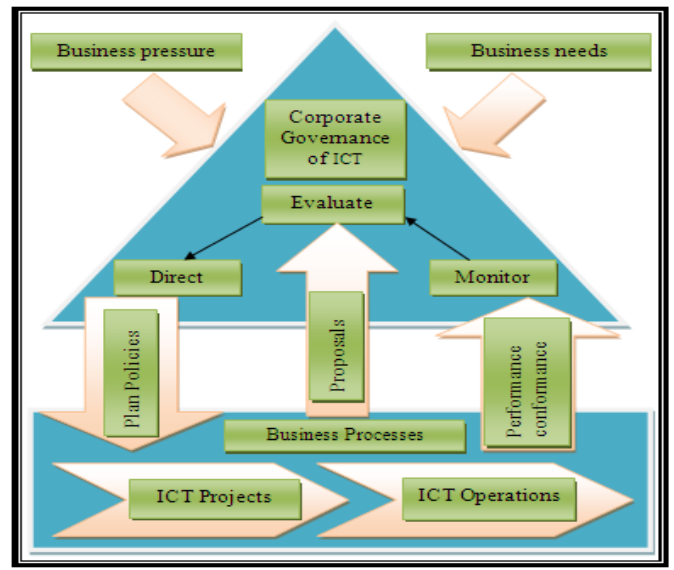

Gambar 3. Australian Standar (AS 8015, 2005)

AS 8015 (2005) mendefinisikan tata kelola TI sebagai suatu sistem memimpin dan mengontrol dengan menggunakan ICT (Information Communication Technology) yang dilakukan pada saat ini dan masa yang akan datang. Hal ini melibatkan suatu evaluasi dan pengarahan suatu rencana untuk menggunakan ICT untuk mendukung organisasi dan memonitor penggunaannya untuk mencapai rencana. Hal ini meliputi strategi dan kebijakan untuk menggunakan ICT di dalam organisasi.

Model ini mendasarkan dirinya pada 6 prinsip dalam "good corporate governance of IT", yaitu:

1. Penerapan tanggung jawab yang dapat dipahami secara jelas.

2. Perencanaan ICT untuk mendukung organisasi.

3. Pengadaan ICT secara valid.

4. Memastikan ICT berjalan baik, kapanpun diperlukan.

5. Memastikan ICT memenuhi aturan-aturan formal.
6. Memastikan ICT memperhatikan faktor manusia.

Dengan kata lain direksi dan komisaris harus mengelola ICT melalui 3 kegiatan utama:

1. Mengevaluasi penggunaan ICT.

2. Mengarahkan penyusunan dan implementasi langsung rencana dan kebijakan.

3. Monitor kesesuaian atas kebijakan dan kinerja terhadap target yang direncanakan.

Model ini juga mengambarkan faktor eksternal yang harus dipenuhi untuk dapat menjalankan ICT Governance. Faktor eksternal tersebut meliputi tekanan bisnis dan kebutuhan bisnis.

Tujuan dari AS8015 ini adalah Efficient, effective, dari penggunaan ICT untuk memberikan suatu hasil kinerja bagi organisasi dengan resiko yang sedikit.

\subsection{Model COBIT}

COBIT merupakan suatu kontrol atas kerangka kerja tata kelola TI dengan menjabarkan mengapa tata kelola TI dibutuhkan, siapa yang memberikan keputusan dan memonitornya, dan keputusan apa yang harus dibuat.

COBIT memberikan keuntungan / manfaat bagi manajer, pengguna TI dan auditor. Manajer memperoleh keuntungan dari COBIT karena menyediakan pondasi untuk membuat keputusankeputusan TI dan investasi TI. Pembuatan keputusan lebih efektif karena COBIT membantu manajemen dalam mendefinisikan perencanaan strategis TI, mendefinisikan arsitektur informasi, mendapatkan hardware dan software TI yang tepat untuk menjalankan strategi TI, memastikan pelayanan yang berkelanjutan, dan memonitor unjuk kerja dari sistem TI. Pengguna TI mendapatkan keuntungan dari COBIT karena menyediakan kepastian kepada mereka jika aplikasi yang membantu dalam pengumpulan, pemrosesan, dan pelaporan informasi sesuai dengan COBIT. Karena COBIT menerapkan kontrol dan keamanan di dalam proses TI. COBIT memberikan keuntungan kepada auditor karena COBIT menolong mereka mengidentifikasikan kepada temuan audit mereka.

COBIT terdiri dari empat domain (COBIT 4.1, 2007):

a. Plan and Organize

b. Acquire and Implement

c. Deliver and Support

d. Monitor and Evaluate

Dengan demikian suatu kontrol objektif TI adalah pernyataan mengenai hasil atau tujuan yang harus dicapai melalui penerapan prosedur kontrol dalam aktifitas tertentu. 
COBIT memberikan panduan yang membantu pihak manajemen untuk menangani atau memenuhi kebutuhan serta persyaratan tata kelola TI yang baik. Untuk itu tersedia seperangkat alat bantu yang bersifat umum (generic) dan dapat digunakan sebagai acuan bagi organisasi dalam menentukan sendiri alat-alat bantu yang bersifat spesifik, yang sesuai bagi organisasinya.

Beberapa alat bantu yang termasuk dalam setiap proses TI dalam COBIT berupa:

1. Daftar CSF atau faktor-faktor kritis penentu kesuksesan

2. Daftar KGI atau indikator-indikator kunci dari suatu tujuan

3. Daftar KPI atau indikator-indikator kunci dari kinerja

4. Maturity Model atau model maturitas untuk membantu dalam melakukan benchmarking dan pembuatan keputusan dalam meningkatkan kapabilitas.

Adapun hubungan antar alat bantu di atas adalah bahwa CSF adalah langkah-langkah atau hal-hal penting yang perlu dilakukan, yang ditetapkan berdasarkan tingkat maturitas yang diinginkan, sementara itu pengawasan terhadap kinerja yang dihasilkan dilakukan dengan menggunakan KPI, untuk melihat apakah tujuan yang ditetapkan melalui KGI telah tercapai.

\subsection{Model organisasi NON-PROFIT}

Model yang dirancang oleh Moore menjelaskan bahwa ada tiga faktor utama yang harus diselaraskan dalam menghasilkan nilai di organisasi, diantaranya:

1. Wilayah kewenangan.

2. Kemampuan yang diberikan.

3. Manfaat yang dapat diberikan kepada masyarakat.

Gambar 4 berikut ini adalah model organisasi non profit.

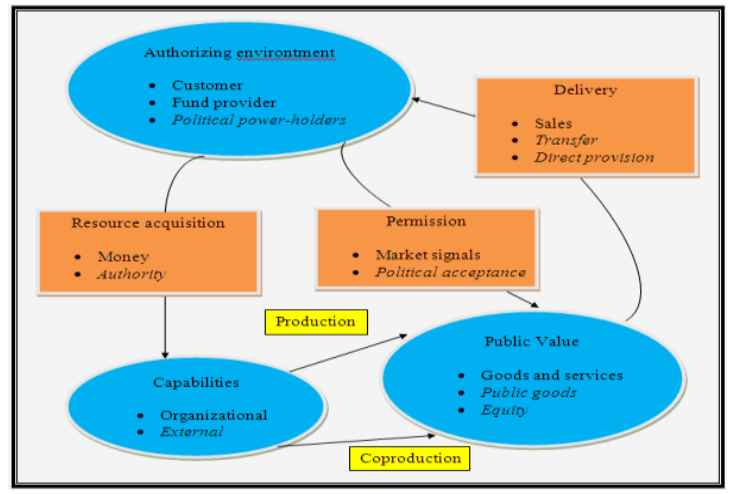

Gambar 4. Model organisasi non profit
Dapat dilihat pada Gambar 2.4 bahwa tulisantulisan yang tercetak miring merupakan unsur-unsur dari pemerintahan diantaranya:

1. Pemegang kekuasaan dalam politik.

2. Kemampuan yang diberikan organisasi kepada masyarakat.

3. Manfaat yang diberikan dapat berupa pelayanan kepada umum atau keadilan.

\subsection{Tata Kelola TI pada Pemerintah}

Suatu tata kelola adalah bagaimana mengubah kebiasaan dalam pengambilan keputusan oleh karena itu pengambilan keputusan harus mengacu kepada prinsip-prinsip dari tata kelola TI (Stacey \& Austin, 2004) diantaranya:

1. Citra yang bersih.

a. Organisasi yang bersih.

b. Kebijakan yang jelas dan standar.

c. Komunikasi yang kuat.

d. Strategi yang jelas.

2. Pemeriksaan secara independent dan peningkatan yang berkelanjutan.

3. Proactive melakukan perubahan manajemen jika manajemen tidak berjalan dengan baik.

4. Bertanggung jawab dan penanganan bisnis operasi yang bersih.

a. Organisasi yang terpercaya.

b. Efektif dalam penggunaan TI.

c. Bertanggung jawab terhadap pengelolaan aset.

5. Proses yang akurat.

\subsection{Mengapa Tata Kelola TI perlu bagi Pemerintah}

Menurut hasil penelitian Weill \& Ross (2004), terdapat lima kunci keputusan tata kelola TI sehingga teknologi informasi adalah sebuah aset yang strategis sebagai berikut:

1. IT principles menjelaskan pernyataanpernyataan eksekutif tentang bagaimana teknologi informasi dapat digunakan organisasi dan kemana arah TI akan dijalankan, prinsip TI menjadi bagian penting dari manajemen organisasi, yang terus didiskusikan dan dilaksanakan demi perbaikan organisasi, baik di sektor pemasaran, keuangan, pabrik dan lain-lain.

2. IT architecture decisions. Arsitektur TI adalah pengorganisasian logika dari data, aplikasi dan infrastruktur yang dikemas dalam suatu kebijakan, hubungan dan pemilihan teknologi untuk mendapatkan integrasi dan standardisasi teknis dan bisnis yang diharapkan. Selain itu teknologi sebagai pendukung bisnis organisasi yang telah dikembangkan melalui IT 
principle, selanjutnya memerlukan proses standardisasi dan integrasi di dalam suatu organisasi. Dalam banyak kasus di Indonesia saat ini banyak persoalan masalah integrasi dan koordinasi, kepentingan sektoral masih menjadi problem, sehingga sering gagalnya proyek IT di perusahaan yang menghabiskan banyak biaya.

3. IT infrastructure. Prasarana dan sarana teknologi informasi yang menyangkut jaringan, komputer, perangkat keras dan lunak lainnya adalah suatu kumpulan komponen yang diharapkan bisa mempercepat proses perhitungan, pengiriman dalam berbagai media informasi (data, informasi, gambar, video, teks) dalam waktu yang singkat dan proses penyimpanan yang efektif. Suatu sarana yang bisa dikontrol dari pusat kekuasaan dan yang dipakai bersama menjadi hal yang penting. Perencanaan kapasitas, baik di penyimpanan, pengiriman maupun pelayanan menjadi penting. Tanpa ada perencanaan yang baik, maka akan menyebabkan buruknya image dan kinerja TI di perusahaan.

4. Business applications needs. Dalam pengembangan teknologi informasi keperluan bisnis yang spesifik sehingga kehadiran teknologi informasi memberikan suatu nilai baru bagi organisasi. Dua hal penting dalam identifikasi keperluan bisnis yang terkait dengan teknologi informasi yaitu kreatifitas dan disiplin. Kreativitas diperlukan untuk mengidentifikasi suatu cara atau proses baru dari perusahaan/organisasi sehingga ada nilai yang bermakna. Sedangkan disiplin menyangkut hal yang berkaitan dengan integritas arsitektur sehingga meyakinkan bahwa aplikasi yang dibangun memang sesuai dengan arsitektur perusahan yang terintegrasi.

5. IT investment and prioritization. Investasi teknologi informasi sering menjadi bahan yang sulit dimengerti oleh top manajemen dari suatu organisasi, hal ini di karenakan nilai yang ada tidak langsung terasa oleh organisasi. Berbeda jika kita membeli mobil baru manfaatnya tentu langsung terasa. Oleh karena itu pemahaman eksekutif maupun komisaris menjadi penting. Berapa biaya yang dikeluarkan? Untuk apa dan bagaimana berkoordinasi dari berbagai kepentingan dan keinginan dari sektor lain.

Kelima dasar yang dikembangkan oleh Weill \& Ross (2004) ini sangat penting dipahami oleh petinggi-petinggi organisasi agar dapat menjadi bagian dari good corporate governance. Tata kelola pemerintahan dengan memanfaatkan teknologi informasi atau yang sering kita sebut sebagai $e$ government yang terus dikembangkan oleh pemerintah perlu melihat ini. Proyek e-government di berbagai daerah masih sering terjadi pemborosan dan tidak berguna, hal ini karena belum dipahami tentang pengembangan teknologi informasi dan belum adanya alat kendali baik oleh eksekutif maupun inspektorat jendral (Depkominfo, 2007).

Menteri Komunikasi dan Informatika Mohammad Nuh dalam sambutan tertulisnya pada Workshop Kode Etik dan Evaluasi Kelompok Kerja Teknologi Informasi dan Komunikasi Nasional (Bappeda Sumbar, 2007), mengatakan bahwa:

"Sebagian besar proyek yang berbasis TI dilingkungan pemerintahan tidak dibarengi dengan tingkat pemahaman prinsip TI yang baik. Prinsipprinsip permasalahan IT Governance yang digunakan dalam pengembangan berbagai proyek pembangunan tersebut masih sangat rendah. Selain itu, hal yang lebih memprihatinkan adalah bahwa proses evaluasi sebuah kegiatan berbasis penggunaan TI di lingkungan pemerintahan masih sangat jarang dilakukan, atau bahkan tidak dikenali sama sekali".

Sebagian besar proyek-proyek tersebut dikatakannya mengalami kegagalan, kurang dapat mencapai sasaran, terbengkalai, serta tumpang tindih. Kasus ini tidak hanya terjadi di unit-unit organisasi pemerintah, tapi juga terjadi di lingkungan dunia usaha nasional. Pemerintahan Indonesia merupakan organisasi yang sangat kompleks, ditambah lagi dengan data dan informasi sumber daya dan kekayaan alam juga memilki tingkat keragaman yang tinggi. Kombinasi yang kompleks ini dan karakter proyek berbasis TIK memberi peluang yang besar pada penyalahgunaan tata kelolanya. Oleh karena itu, ditegaskannya bahwa pemahaman yang mendalam mengenai tata kelola TI dan evaluasi TIK menjadi hal mendasar yang tidak bisa ditawar lagi dan harus dikuasai di lingkungan pemerintahan.

Ketua kelompok kerja (Pokja) Evaluasi TIK Nasional (Detiknas, 2006) mengatakan bahwa:

"Perlunya suatu kerangka yang kuat dan terorganisasi dalam membangun tata kelola TI. Anggaran tata kelola TI sangat besar, jika tidak ada tata kelola yang baik dan benar peluang terjadi kecurangan akan sangat besar. Selain tata kelola yang baik, kode etik dan piagam evaluasi pokok kerja TIK perlu diterbitkan agar diketahui dan ada kesepahaman antara pejabat pemerintahan dan pihak-pihak terkait lainnya". 
Manfaat Penerapan ICT Governance di Institusi Pemerintah

Nasional

a. Koordinasi dan integrasi Rencana TI Nasional

b. Mendapatkan standar rujukan kualitas penyelenggaraan TI di seluruh institusi pemerintahan

c. Memudahkan monitoring dan evaluasi penyelenggaraan TI di seluruh institusi pemerintahan

Institusional

a. Mendapatkan batasan dan panduan sesuai dengan best practice dalam penyelenggaraan TI-nya dilingkungan masing-masing

b. Mengoptimalkan ketercapaian value dari penyelenggaraan TI di lingkungan kerjanya masingmasing: internal manajemen \& pelayanan publik

Publik

a. Mendapatkan kualitas pelayanan publik yang lebih baik

b. Transparansi kriteria batasan penyelenggaraan TI oleh institusi pemerintah, sehingga dapat melakukan fungsi

Gambar 5. Manfaat penerapan ICT Governance (Detiknas, 2007)

\subsection{Kebutuhan Tata Kelola TI pada Pemerintah}

Bappenas sebagai institusi perencana pada pemerintah tentu harus membantu pengembangan ICT yang sedang dikembangkan Dewan Teknologi Informasi Komunikasi Nasional dalam rangka percepatan penerapan ICT di Indonesia termasuk tata kelola TI didalamnya. Gambar 5 berikut manfaat penerapan ICT Governance di Institusi Pemerintah (Detiknas, 2007).

Bappenas sebagai badan perencana terlibat dalam proyek TI skala nasional seperti tujuh flagship yang ditetapkan oleh Dewan Teknologi Informasi dan Komunikasi Nasional (DTIKN), diantaranya e-procurement, e-anggaran, National Single Window, e-education, Palapa Ring, legalisasi software pemerintah, dan nomor identitas nasional. Bappenas bertanggung jawab dalam proyek e-procurement dan sudah berhasil diterapkan, hasil dari proyek itu dikeluarkan dalam bentuk Keppres 80 tentang pengadaan barang dan jasa.

\subsection{Good Public Governance}

Istilah good public governance mengandung makna tata kepemerintahan yang baik, pengelolaan pemerintahan yang baik, serta dapat pula diungkapkan sebagai penyelenggaraan pemerintahan yang baik, penyelenggaraan negara yang baik atau pun administrasi negara yang baik. Istilah tata kepemerintahan yang baik (good public governance) merupakan suatu konsepsi tentang penyelenggaraan pemerintahan yang bersih, demokratis, dan efektif. Selain sebagai suatu konsepsi tentang penyelenggaraan pemerintahan, tata kepemerintahan yang baik juga merupakan suatu gagasan dan nilai untuk mengatur pola hubungan antara pemerintah, dunia usaha swasta, dan masyarakat.

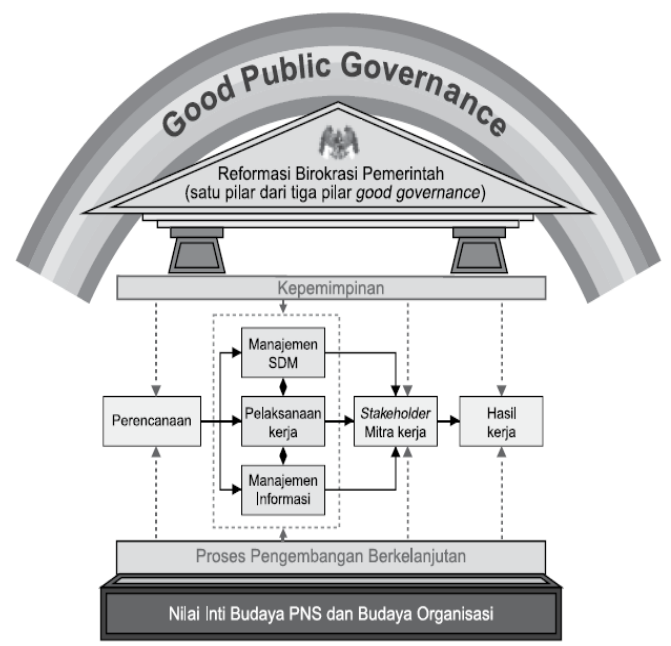

Gambar 6. Good public governance (Bappenas, 2007)

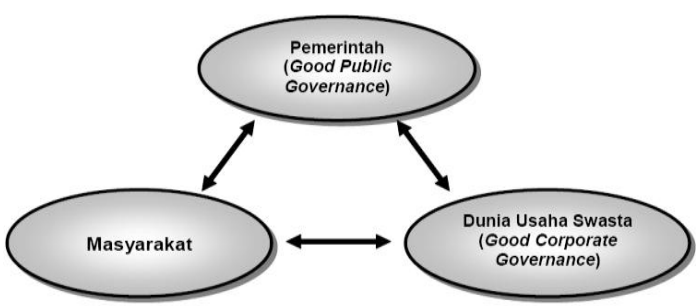

Gambar 7. Keseimbangan tiga pilar (Bappenas, 2007)

Salah satu upaya untuk mewujudkan pelaksanaan kepemerintahan yang baik (good governance) adalah reformasi birokrasi seperti gambar yang ada di bawah. Birokrasi sebagai organisasi formal memiliki kedudukan dan cara kerja yang terikat dengan peraturan, memiliki kompetensi sesuai jabatan dan pekerjaan, memiliki semangat pelayanan publik, pemisahan yang tegas antara milik organisasi dan individu, serta sumber daya organisasi yang tidak bebas dari pengawasan eksternal.

Upaya untuk mewujudkan tata kepemerintahan yang baik hanya dapat dilakukan apabila terjadi keseimbangan peran ketiga pilar yaitu pemerintah, dunia usaha swasta, dan masyarakat (Gambar 7).

Ketiganya mempunyai peran masing-masing. Pemerintahan (legislatif, eksekutif, dan yudikatif) 
memainkan peran menjalankan dan menciptakan lingkungan politik dan hukum yang kondusif bagi unsur-unsur lain dalam governance. Dunia usaha swasta berperan dalam penciptaan lapangan kerja dan pendapatan. Masyarakat berperan dalam penciptaan interaksi sosial, ekonomi dan politik. Ketiga unsur tersebut dalam memainkan perannya masing-masing harus sesuai dengan nilai-nilai dan prinsip-prinsip yang terkandung dalam tata kepemerintahan yang baik.

Agenda penciptaan tata kepemerintahan yang baik setidaknya memiliki 5 (lima) sasaran yaitu:

1. Berkurangnya secara nyata praktek korupsi kolusi dan nepotisme di birokrasi, yang dimulai dari jajaran pejabat yang paling atas;

2. Terciptanya sistem kelembagaan \& ketatalaksanaan pemerintah yang efisien, efektif dan profesional transparan dan akuntabel;

3. Terhapusnya peraturan dan praktek yang bersifat diskriminatif terhadap warga negara;

4. Meningkatnya partisipasi masyarakat dalam pengambilan kebijakan publik;

5. Terjaminnya konsistensi seluruh peraturan pusat dan daerah.

Penerapan tata kepemerintahan yang baik di lingkungan pemerintahan tidak terlepas dari penerapan sistem manajemen kepemerintahan yang merupakan rangkaian hasil dari pelaksanaan fungsifungsi manajemen (planning, organizing, actuating, dan controlling) yang dilaksanakan secara profesional dan konsisten. Penerapan sistem manajemen tersebut mampu menghasilkan kemitraan positif antara pemerintah, dunia usaha swasta, dan masyarakat. Dengan demikian, lingkungan instansi pemerintah diharapkan dapat memberikan pelayanan prima kepada masyarakat (Bappenas, 2007).

\subsection{Penelitian Terdahulu Model Tata Kelola TI}

Penelitian-penelitian terdahulu digunakan sebagai masukan dalam perbandingan model yang akan digunakan.

\subsubsection{Review 17 Model Tata Kelola TI}

Dapat dilihat pada Tabel 2.2 berikut ini bahwa model COBIT, Weill \& Ross, ITGI, dan Peterson memang suatu model tata kelola TI pada aspek proses pembuatan keputusan dan lebih menitikberatkan pada pengambilan keputusan untuk bisnis sistem dalam artian keseluruhan proses bisnis, sedangkan COBIT lebih menitik-beratkan pada bagaimana melakukannya (Michael Holm Larsen, Mogens Kuns Pederson, Kim Viborg Andersen, 2006).
Tabel 2. Review 17 Tools IT Governance

\begin{tabular}{|c|c|c|c|c|}
\hline $\begin{array}{l}\text { Decision- } \\
\text { making } \\
\text { processes }\end{array}$ & SAS70 & COBIT & & $\begin{array}{c}\text { Tata kelola TI } \\
\text { Review (Weill } \\
\text { \& Ross) } \\
\text { Tata Kelola TI } \\
\text { Assessment } \\
\text { (Weill \& Ross) } \\
\text { Tata Kelola TI } \\
\text { Checklist } \\
\text { (ITGI) } \\
\text { Tata Kelola TI } \\
\text { Assessment } \\
\text { Process Model } \\
\text { (Peterson) }\end{array}$ \\
\hline $\begin{array}{c}\text { Core business } \\
\text { processes }\end{array}$ & $\begin{array}{c}\text { ITIL/BS } \\
15000\end{array}$ & $\begin{array}{c}\text { CMM/ } \\
\text { CMMI } \\
\text { IT Audit } \\
\text { IT Due } \\
\text { Diligence }\end{array}$ & $\begin{array}{c}\text { Six } \\
\text { Sigma }\end{array}$ & $\begin{array}{c}\text { IT Service } \\
\text { CMM }\end{array}$ \\
\hline $\begin{array}{c}\text { Support } \\
\text { processes }\end{array}$ & $\begin{array}{c}\text { ISO 17799/ } \\
\text { BS } 7799 \\
\text { Sys Trust }\end{array}$ & $\begin{array}{c}\text { ASL } \\
\text { PRINCE2 }\end{array}$ & & SOX \\
\hline $\begin{array}{c}\text { Process typel } \\
\text { organizational } \\
\text { Entity }\end{array}$ & Procedure & Activity & $\begin{array}{c}\text { Business } \\
\text { unit }\end{array}$ & Business sstem \\
\hline
\end{tabular}

\subsubsection{Perbandingan COBIT, ITIL,COSO,ISO 17799, dan AS 8015-2005}

Hasil dari penelitian ini menjelaskan mengenai perbandingan Model tata kelola TI diantaranya:

- COBIT

COBIT menyediakan proses-proses penting tata kelola TI yang dibagi dalam keempat domainnya. COBIT memberikan deskripsi control objective atas setiap proses, dari ke-34 proses yang dimilikinya; dilengkapi pula dengan CSF, KPI, KGI, maturity level untuk setiap prosesnya. COBIT paling mendekati prinsip-prinsip model tata kelola TI. COBIT 4.0 memberikan konteks bisnis yang lebih kuat dibandingkan dengan COBIT 3.0 keterkaitan antar proses dan bagaimana dinamika peran untuk setiap proses berhasil didefinisikan walaupun masih sangat high level.

Merujuk pada persyaratan tata kelola TI yang efektif menurut Weill \& Ross COBIT lebih cenderung ke bagaimana keputusan-keputusan itu dibuat dan dimonitor. Karena berorientasi pada proses, keputusan yang dibuat dalam manajemen dan penggunaan TI juga selalu bereferensi kepada proses. Walaupun ITGI sudah mempublikasikan "IT Governance Implementation guide", tetapi kesulitan utama dalam implementasi COBIT adalah apakah semua control objective dan detailed control objective harus diadopsi, ataukah sebagian saja? Bagaimana memilihnya?

- ITIL

ITIL, beserta BS 1500, merupakan framework yang mempunyai konstruksi sistematika kerja yang paling lengkap, mencakup ketiga prinsip framework 
tata kelola TI yang digunakan untuk analisa dalam penelitian ini. Tetapi cakupan proses yang dimiliki ITIL tidaklah sekomprehensif COBIT, karena memang pada awalnya filosofi yang mendasari munculnya ITIL adalah IT service Management. Filosofi sistematika ITIL jika digabungkan dengan lingkup proses COBIT, secara ilmiah dapat membentuk sebuah konstruksi tata kelola TI yang solid.

\section{- $\mathrm{COSO}$}

Kelebihan COSO adalah pada konstruksi kontrolnya, keterkaitan general control dan application control. Ini dapat dimaklumi karena COSO lebih mengkonsentrasikan diri pada internal control framework, khususnya dalam keterkaitannya dengan laporan keuangan. Karena itu, COSO lebih pada IT Control Framework, dari pada sebuah control tata kelola TI. Karena fokus kepada internal control framework, maka sistematika control COSO jika diterapkan pada COBIT akan membuat control objectives COBIT lebih implementatif. Karena fokus pada laporan keuangan, COSO juga diadopsi sebagai standar untuk implementasi kontrol TI dalam konteks compliance atas Sarbanes Oxley (SOX).

- ISO 17799

Identik dengan COBIT dan COSO, ISO 17799 lebih cenderung sebagai IT Control Framework dalam konteks keamanan informasi daripada sebuah Tata kelola TI Framework. Walaupun ISO 17799 memiliki panduan siklus PDCA (Plan, Do, Check, Act) sebagai proses utama implementasinya dan beberapa poin persyaratan terkait struktur peran yang harus ada dalam manajemen keamanan informasi, tetapi lingkup bahasan ISO 17799 terlalu sempit untuk sebuah tata kelola TI.

- AS 8015-2005

Standar ini sangat singkat, dapat diimplementasikan di semua jenis organisasi yang ada di Australia, mencakup perusahaan terbuka/pribadi, instansi pemerintahan, dan organisasi nirlaba. Tetapi untuk dapat dikatakan sebagai model tata kelola TI, AS 8015-2005 terlalu sempit karena lebih diposisikan sebagai kontrol Model yang dapat digunakan berbagai kalangan (Basuki Rahmad \& Suhono Harso Supangkat, 2006).

\section{Metodologi}

Metodologi perancangan dilakukan dengan menggunakan metode perancangan model tata kelola TI yang dihasilkan dari tahapan studi pustaka. Rancangan model tata kelola dibuat sesuai dengan karakteristik dan kebutuhan organisasi berdasarkan hasil analisis organisasi.

Tahap-tahap perancangan model organisasi untuk studi kasus Bappenas dijelaskan sebagai berikut:

1. Analisa model tata kelola TI di Bappenas dengan menggunakan 5 model tata kelola TI.

2. Dari analisa no.1 dilakukan analisa organisasi yang diterapkan di Bappenas, seperti bentuk perintah yang berlaku di Bappenas, kewenangan, kebijakan dan tren teknologi yang mungkin diterapkan.

3. Menyusun metode perancangan tata kelola TI yang sesuai dengan Bappenas.

4. Identifikasi tujuan Bappenas dan Tujuan Pusdatin dengan mekanisme tata kelola TI.

5. Identifikasi struktur, proses dan mekanisme hubungan yang terjadi di Bappenas menggunakan model Peterson.

6. Identifikasi pola pengambilan keputusan TI menggunakan model Weill \& Ross.

7. Identifikasi fokus area tata kelola TI menggunakan model ITGI.

8. Identifikasi proses-proses monitor, evaluasi dan arahan sekaligus faktor penekan dari bisnis dan kebutuhan bisnis, faktor penghambat dan faktor pendukung menggunakan AS 8015

9. Menentukan proses-proses TI dari permasalahan yang didapat pada model Peterson, model Weill \& Ross, model ITGI, model AS 8015 dan COBIT..

10. Menentukan kontrol proses TI yang harus dilakukan oleh Bappenas menggunakan COBIT.

11. Kesimpulan dan saran.

\section{Pembahasan}

Pada bagian ini akan diuraikan hasil pembahasan terhadap analisis model tata kelola TI.

\subsection{Analisa Model Tata Kelola TI}

Untuk melakukan analisa atas model yang telah dijelaskan sebelumnya, digunakan prinsip-prinsip utama yang harus dapat dipenuhi oleh sebuah model tata kelola TI. Prinsip-prinsip tersebut akarnya dapat diambil dari pemberian definisi atas tata kelola TI di penjelasan terdahulu, jika disimpulkan, setidaknya prinsip-prinsip tersebut bermuara pada adanya leadership, struktur, proses, mekanisme hubungan TI dan kebutuhan bisnis, kontrol atas formulasi dan implementasi TI. Prinsip efektifitas tata kelola TI hasil penelitian Weill dan Ross dapat digunakan sebagai prinsip-prinsip model tata kelola TI diantaranya: 
1. Keputusan-keputusan apa saja yang harus dibuat untuk memastikan efektifitas manajemen dan penggunaan TI?

2. Siapa yang seharusnya membuat keputusankeputusan tersebut?

3. Bagaimana keputusan-keputusan tersebut dibuat dan dimonitor?

Selain itu melihat dari 6 prinsip dalam "good corporate governance of IT", yaitu:

1. Penerapan tanggung jawab yang dapat dipahami secara jelas.

2. Perencanaan $I C T$ untuk mendukung organisasi.

3. Pengadaan $I C T$ secara valid.

4. Memastikan ICT berjalan baik, kapanpun diperlukan.

5. Memastikan ICT memenuhi aturan-aturan formal.

6. Memastikan ICT memperhatikan faktor manusia.

Mengacu juga pada komponen utama dari tata kelola TI (Gartner, 2006)

1. Apakah keputusan yang perlu dibuat?

2. Siapakah yang memutuskan dan memberi masukan?

3. Bagaimana keputusan tersebut terbentuk dan berperan?

Tabel 3. Fokus-fokus model tata kelola TI

\begin{tabular}{|l|c|c|c|c|c|}
\hline Fokus Model & Peterson & Weill\&Ross & ITGI & AS 8015 & COBIT \\
\hline $\begin{array}{l}\text { Structure/Decision } \\
\text { Making Structure }\end{array}$ & $\sqrt{ }$ & $\sqrt{ }$ & & & \\
\hline $\begin{array}{l}\text { Processes/ } \\
\text { Alignment Process/ } \\
\text { IT Strategic } \\
\text { Alignment }\end{array}$ & $\sqrt{ }$ & $\sqrt{ }$ & $\sqrt{ }$ & & $\sqrt{ }$ \\
\hline $\begin{array}{l}\text { Relational } \\
\text { Mechanism/ } \\
\text { Comunication } \\
\text { Approach }\end{array}$ & $\sqrt{ }$ & $\sqrt{ }$ & & & \\
\hline $\begin{array}{l}\text { Stakeholder Value } \\
\text { Drivers/Business } \\
\text { Pressures/Business } \\
\text { Needs }\end{array}$ & & & $\sqrt{ }$ & $\sqrt{ }$ & $\sqrt{ }$ \\
\hline IT Value Delivery & $\sqrt{ }$ & $\sqrt{ }$ & $\sqrt{ }$ & $\sqrt{ }$ & $\sqrt{ }$ \\
\hline $\begin{array}{l}\text { Risk Management } \\
\text { Performance } \\
\text { Measurement }\end{array}$ & $\sqrt{ }$ & $\sqrt{ }$ & $\sqrt{ }$ & $\sqrt{ }$ & $\sqrt{ }$ \\
\hline $\begin{array}{l}\text { IT Resource } \\
\text { Management }\end{array}$ & & & $\sqrt{ }$ & $\sqrt{ }$ & $\sqrt{ }$ \\
\hline Monitor & & & & $\sqrt{ }$ & $\sqrt{ }$ \\
\hline Evaluate & & & & $\sqrt{ }$ & $\sqrt{ }$ \\
\hline Direct & & & & & $\sqrt{ }$ \\
\hline Plan and Organize & & & & & $\sqrt{ }$ \\
\hline $\begin{array}{l}\text { Acquire and } \\
\text { Implement }\end{array}$ & & & & & $\sqrt{ }$ \\
\hline $\begin{array}{l}\text { Deliver and } \\
\text { Support }\end{array}$ & & & & & \\
\hline $\begin{array}{l}\text { Monitor and } \\
\text { Evaluate }\end{array}$ & & & & & \\
\hline
\end{tabular}

Berdasarkan keseluruh prinsip diatas, sebelum dilakukan analisa atas keseluruhan model yang ada maka terlebih dahulu dilakukan pemetaan terhadap fokus-fokus masing-masing model tata kelola TI tersebut.

Dapat dilihat pada tabel 3 perbandingan model tata kelola TI bahwa masing-masing model memiliki keterkaitan satu dengan yang lainnya, pada model COBIT dapat dilihat mempunyai cakupan fokus paling lengkap karena memang COBIT merupakan control objective dari tata kelola TI tapi pada level activity, berikut hasil pemetaan keseluruhan model ke COBIT.

Melihat keterkaitan yang ada pada Tabel 4 maka dilakukan analisa atas keterkaitan antar modelmodel tersebut, masing-masing model mempunyai kesamaan antara satu yang lainnya. Tabel 5 berikut merupakan hasil dari analisa tersebut.

Dari Tabel 5 terlihat bahwa masing-masing model ternyata memiliki keterkaitan antara satu dengan yang lainnya sehingga model-model tersebut akan menjadi komprehensif jika digabungkan keseluruhannya. Dari model Peterson dan model Weill \& Ross ada kemiripan dalam sisi struktur beserta pengambilan keputusannya, mekanisme hubungan beserta pendekatan komunikasinya. Selain itu fokus Weill \& Ross pada proses keselarasan ada keterkaitan dengan alignment process pada ITGI. Pada model ITGI dimana performance measurement pun terkait dengan performance pada AS 8015. Pada proses monitor, evaluate terkait sekali dengan model yang ada pada COBIT.

Dari keterkaitan-keterkaitan yang ada pada masing-masing model ternyata antara satu dengan yang lainnya saling melengkapi pada setiap prosesprosesnya. Dapat dilihat pada Weill \& Ross, tidak melihat struktur tapi hanya melihat pengambilan keputusannya saja. Hal tersebut teratasi oleh model Peterson. Kesemua model tersebut menjadi komprehensif jika digabung secara keseluruhan dengan mempertimbangkan faktor-faktor apa yang menjadi ciri khas dari studi kasus.

Dari Gambar 8 di bawah dapat dijelaskan bahwa Bappenas sebagai Badan Perencanaan mempunyai tujuan yang harus dijalankan oleh divisi-divisi yang terkait termasuk pusdatin, tujuan dari Bappenas didukung dengan tujuan pusdatin selain itu keinginan dan kebutuhan dari bisnis termasuk keinginan stakeholder merupakan pendorong utama agar TI mempunyai nilai bagi Bappenas. Selain itu faktor-faktor diatas merupakan suatu faktor utama agar penerapan tata kelola TI dapat berjalan dengan baik. 
Tabel 4. Pemetaan model tata kelola TI ke COBIT

\begin{tabular}{|c|c|c|c|c|}
\hline & Peterson & Weill \& Ross & AS 8015 & ITGI \\
\hline & Structure & IT Principles & $\begin{array}{c}\text { Corporate } \\
\text { Governance ICT }\end{array}$ & $\begin{array}{l}\text { Strategic } \\
\text { Alignment }\end{array}$ \\
\hline & Process & IT Architecture & Business Process & Value Delivery \\
\hline & $\begin{array}{l}\text { Relational } \\
\text { Mechanism }\end{array}$ & $\begin{array}{c}\text { IT Infrastructure } \\
\text { Strategies }\end{array}$ & Business Pressure & $\begin{array}{c}\text { Resource } \\
\text { Management }\end{array}$ \\
\hline & & $\begin{array}{l}\text { Business Application } \\
\text { Needs } \\
\end{array}$ & Business Needs & $\begin{array}{l}\text { Performance } \\
\text { Measurement }\end{array}$ \\
\hline & & IT Investment & & \\
\hline Plan and Organise & & & & \\
\hline PO1 Define strategic IT Plan & & & & \\
\hline PO2 Define the information architecure & & & & \\
\hline PO3 Determine technological direction & & & & \\
\hline $\begin{array}{l}\text { PO4 Define the IT processes, organization, and } \\
\text { relationships }\end{array}$ & & & & \\
\hline PO5 Manage the IT investment & & & & \\
\hline $\begin{array}{l}\text { PO6 Communicate management aims and } \\
\text { directions }\end{array}$ & & & & \\
\hline PO7 Manage the IT human resources & & & & \\
\hline PO8 Manage Quality & & & & \\
\hline PO9 Access and manage IT risks & & & & \\
\hline PO10 Manage projects & & & & \\
\hline Acquire and Implement & & & & \\
\hline AI1 Identify automated solutions & & & & \\
\hline AI2 Acquire and maintain application software & & & & \\
\hline $\begin{array}{l}\text { AI3 Acquire and maintain technology } \\
\text { infrastructure }\end{array}$ & & & & \\
\hline AI4 Enable operation and use & & & & \\
\hline AI5 Procure IT reaources & & & & \\
\hline AI6 Manage changes & & & & \\
\hline AI7 Install and accredit solutions and changes & & & & \\
\hline Deliver and Support & & & & \\
\hline DS1 Define and manage service levels & & & & \\
\hline DS2 Manage third-party services & & & & \\
\hline DS3 Manage performance and capacity & & & & \\
\hline DS4 Ensure continous service & & & & \\
\hline DS5 Ensure systems security & & & & \\
\hline DS6 Identiry and allocate costs & & & & \\
\hline DS7 Educate and train users & & & & \\
\hline DS8 Manage service desk and incidents & & & & \\
\hline DS9 Manage the configurations & & & & \\
\hline DS10 Manage problems & & & & \\
\hline DS11 Manage data & & & & \\
\hline DS12 Manage the physical environment & & & & \\
\hline DS13 Manage operations & & & & \\
\hline Monitor and Evaluate & & & & \\
\hline ME1 Monitor and evaluate IT performance & & & & \\
\hline ME2 Monitor and evaluate internal control & & & & \\
\hline $\begin{array}{l}\text { ME3 Ensure compliance with external } \\
\text { requirements }\end{array}$ & & & & \\
\hline ME4 Provide IT governance & & & & \\
\hline
\end{tabular}

Pusdatin sebagai Divisi TI pada Bappenas akan mengeluarkan solusi-solusi berdasarkan keinginan dari bisnis maupun inisiatif dari TI sendiri bagi Bappenas sendiri maupun bagi Departemen yang lain, solusinya diantaranya E-Monnef, $E$ Procurement, E-Planning dalam penerapannya tentu memerlukan suatu mekanisme yang dapat menciptakan keseluruhan proses itu berjalan dengan baik dan lancar, mulai dari siapa yang bertanggung jawab, bagaimana proses koordinasi antara TI dan bisnis, bagaimana mekanisme koordinasinya setelah proses itu dijalankan, kemudian diperlukan suatu mekanisme kontrol atas proses yang dijalankan, apakah benar sesuai prosedur atau tidak didalamnya, bagaimana mengukur kinerjanya, apakah TI sudah mempertimbangkan resiko, apakah sumber dayanya sudah mencukupi, proses-proses yang dilakukan merupakan wewenang siapa, adakah kebijakan yang dikeluarkan agar proses investasi TI-nya dapat berjalan dengan baik, kesemuanya itu bermuara pada TI dapat memberikan nilai bagi Bappenas 
Tabel 5. Analisa perbandingan model tata kelola TI

\begin{tabular}{|c|c|c|c|c|}
\hline Peterson & Weill \& Ross & ITGI & AS 8015 & COBIT \\
\hline $\begin{array}{l}\text { Pengaturan yang bersifat } \\
\text { top level. }\end{array}$ & $\begin{array}{l}\text { Sudut pandang dalam } \\
\text { pengambilan keputusan. }\end{array}$ & $\begin{array}{l}\text { Fokus area dari Tata } \\
\text { kelola TI. }\end{array}$ & $\begin{array}{l}\text { Mengacu pada konsep } \\
\text { GCG. }\end{array}$ & One size fit all. \\
\hline $\begin{array}{l}\text { Penekanan pada struktur } \\
\text { organisasi, mekanisme } \\
\text { hubungan dan proses } \\
\text { investasinya secara } \\
\text { keseluruhan termasuk di } \\
\text { dalamnya monitoring } \\
\text { dan evaluasinya. }\end{array}$ & $\begin{array}{l}\text { Konsep what, who dan } \\
\text { how dalam pengambilan } \\
\text { keputusan. }\end{array}$ & $\begin{array}{l}\text { Orientasi pada proses- } \\
\text { proses yang harus } \\
\text { dilakukan dalam } \\
\text { penerapan Tata kelola TI }\end{array}$ & $\begin{array}{l}\text { Pengaturan yang bersifat } \\
\text { top level }\end{array}$ & $\begin{array}{l}\text { Konsep why, who dan } \\
\text { what dalam pengambilan } \\
\text { keputusan. }\end{array}$ \\
\hline $\begin{array}{l}\text { Mekanisme hubungan } \\
\text { merupakan faktor } \\
\text { keselarasan antara TI- } \\
\text { Bisnis. }\end{array}$ & $\begin{array}{l}\text { Pengaturan yang bersifat } \\
\text { top level. }\end{array}$ & $\begin{array}{l}\text { Adanya strategi untuk } \\
\text { mencapai keselarasan } \\
\text { antara TI-Bisnis. }\end{array}$ & $\begin{array}{l}\text { Proses lebih ditekankan } \\
\text { pada aspek monitor, } \\
\text { evaluate dan direct } \\
\text { berdasarkan keinginan } \\
\text { bisnis dan tekanan dari } \\
\text { bisnis. }\end{array}$ & $\begin{array}{l}\text { Kuat dalam checklist jika } \\
\text { mengaudit }\end{array}$ \\
\hline $\begin{array}{l}\text { Berorientasi pada } \\
\text { pengambilan keputusan } \\
\text { secara keseluruhan. }\end{array}$ & $\begin{array}{l}\text { Berorientasi pada } \\
\text { pengambilan keputusan } \\
\text { secara spesifik. }\end{array}$ & Bersifat praktis. & $\begin{array}{l}\text { Adanya siklus antara TI- } \\
\text { Bisnis mulai dari bisnis } \\
\text { mengajukan proposal } \\
\text { sampai dengan proyek } \\
\text { dihasilkan dan } \\
\text { pengukuran kinerja TI } \\
\text { merupakan keselarasan } \\
\text { antara TI-Bisnis. }\end{array}$ & $\begin{array}{l}\text { Sudut pandang kontrol } \\
\text { dan pelaksanaan kontrol } \\
\text { pada tingkat manajemen. }\end{array}$ \\
\hline $\begin{array}{l}\text { Cocok untuk pengaturan } \\
\text { atau pembentukan } \\
\text { (setting up) Tata kelola } \\
\text { TI (top-down). }\end{array}$ & $\begin{array}{l}\text { Pendekatan komunikasi } \\
\text { merupakan faktor } \\
\text { keselarasan antara TI- } \\
\text { Bisnis. }\end{array}$ & & Bersifat praktis. & Berorientasi pada action. \\
\hline Bersifat teoritis. & $\begin{array}{l}\text { Domain berupa bidang- } \\
\text { bidang keputusan TI } \\
\text { yang sifatnya } \\
\text { fundamental. }\end{array}$ & & & $\begin{array}{l}\text { Domain berupa bidang } \\
\text { dalam siklus manajemen } \\
\text { umum. }\end{array}$ \\
\hline & $\begin{array}{l}\text { Cocok untuk pengaturan } \\
\text { atau pembentukan } \\
\text { (setting up) Tata kelola } \\
\text { TI (top-down). }\end{array}$ & & & $\begin{array}{l}\text { Cocok untuk monitoring } \\
\text { proses TI untuk } \\
\text { membantu tercapainya } \\
\text { pelaksanaan Tata kelola } \\
\text { TI yang baik. }\end{array}$ \\
\hline & Bersifat teoritis. & & & Bersifat praktis. \\
\hline
\end{tabular}

sendiri dan Pemerintah pada umumnya. Dari kesemuanya itu dapat dilihat juga faktor pendukung dan faktor penghambat dalam tata kelola TI di Bappenas sehingga dari faktor-faktor di atas dapat dihasilkan suatu tata kelola TI yang sesuai bagi Bappenas.

\subsection{Kondisi yang ada}

SIB merupakan aplikasi surat dinas yang digunakan secara bersama. Dengan adanya aplikasi ini, user dapat mendisposisikan pekerjaan, maupun mengirim memo kapanpun dan dimanapun juga. Akan tetapi dalam penerapannya, muncul beberapa kubu:

1. Kubu 1: pihak yang sangat mendukung dan menggunakan aplikasi ini dalam kegiatannya sehari-hari

2. Kubu 2: pihak yang mendukung, tetapi tidak menggunakannya secara penuh (malas-malasan)

3. Kubu 3: pihak yang tidak mendukung/resisten

Pusdatin, sebagai unit kerja pengusul dalam

pengembangan SIB, tidak memiliki kekuasaan untuk menekan unit kerja lain. Hal ini disebabkan karena struktur organisasi Pusdatin yang hanya berada pada jajaran Eselon II.

\subsection{Pemetaan-pemetaan Menggunakan Model Tata Kelola TI}

Berikut pemetaan yang dilakukan dengan menggunakan model tata kelola TI.

Tabel 6. Struktur

\begin{tabular}{|l|l|}
\hline Fokus Struktur & Keterangan \\
\hline Posisi Pusdatin & Berada pada eselon dua \\
\hline Bentuk Organisasi & Centralized \\
\hline IT Steering Commitee & Tidak ada rapat internal \\
\hline IT Strategic Commitee & Tidak ada rapat internal \\
\hline IT Leadership & $\begin{array}{l}\text { CIO-nya Kapusdatin } \\
\text { sendiri }\end{array}$ \\
\hline $\begin{array}{l}\text { Hubungannya dengan } \\
\text { Bappeda }\end{array}$ & Bersifat koordinasi \\
\hline
\end{tabular}




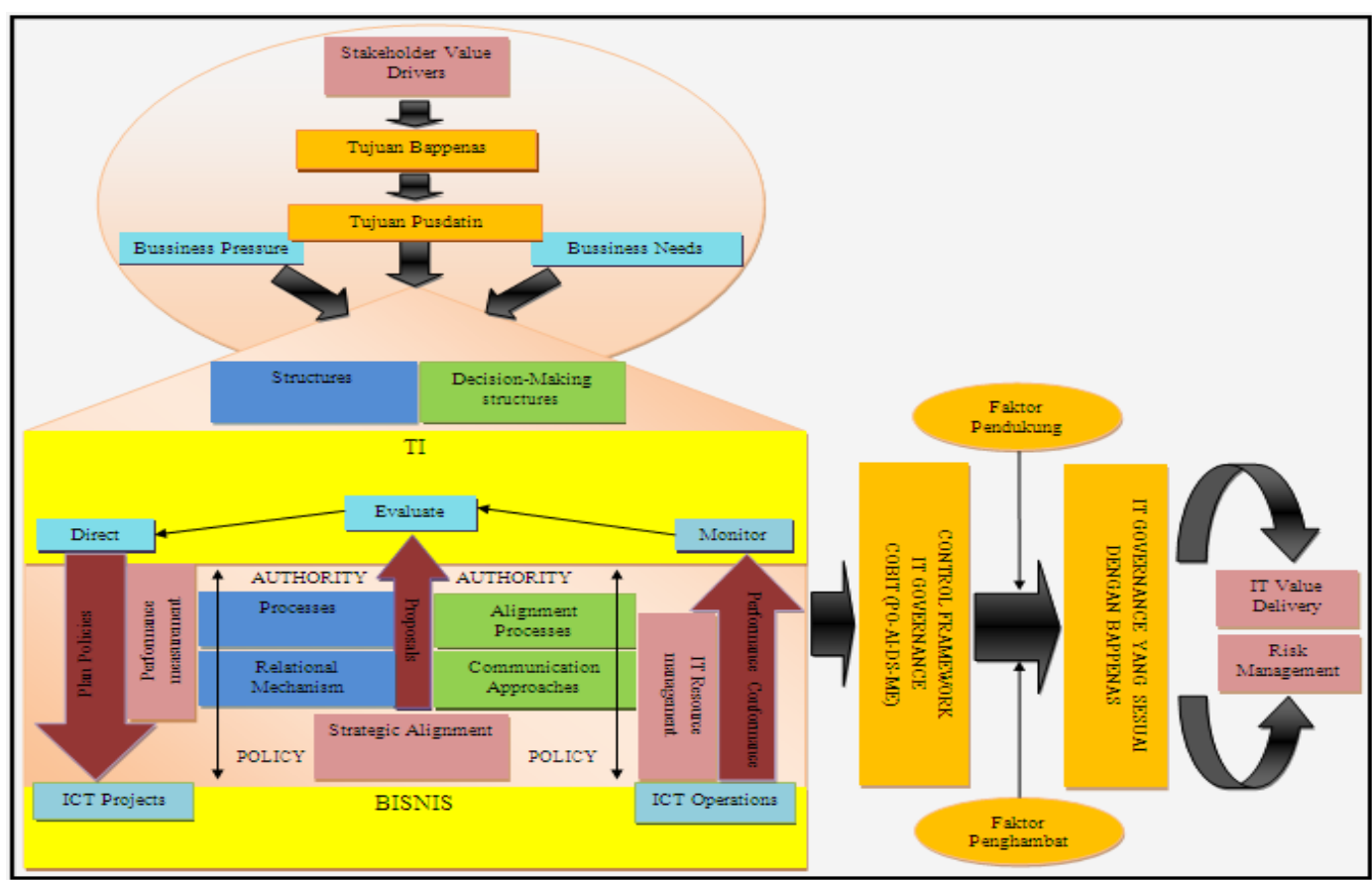

Gambar 8. Gabungan model tata kelola TI untuk Bappenas

\subsubsection{Struktur}

Tabel 6 di atas menjelaskan struktur organisasi di Bappenas. Dimana posisi Pusdatin masih berada pada eselon dua, yang mana pada kenyataanya sulit mengambil keputusan karena kewenangan yang terbatas.

Untuk pengembangan proyek TI, Bappenas tidak mengenal istilah commitee, baik IT Steering Commitee maupun IT Strategic Commitee. Yang ada hanya rapat internal untuk mengkaji masalah perumusan strategi TI.

\subsubsection{Proses}

Gambar 9 menjelaskan proses pengelolaan proyek TI yang dimulai dengan usulan investasi TI dari unit kerja pengusul (UKE-II) sesuai dengan kebutuhan masing-masing unit. Tetapi, sebelum mengusulkan sebuah proyek TI, terlebih dahulu dilakukan kajian untuk melakukan studi kelayakan (feasibility study) dan menetapkan Rencana Anggaran Belanja (RAB) terhadap proyek TI yang akan dilaksanakan.

Setelah kajian selesai, maka diserahkan ke UKE I untuk disetujui. Setelah dilakukan kajian, maka proyek TI diajukan kepada Biro Renortala yang berpedan dalam melakukan pengumpulan usulan kegiatan dari seluruh unit kerja di Bappenas. Selanjutnya akan di nilai oleh Tim Anggaran sebagai tim penilai usulan dan rincian anggaran. Kemudian tim Anggaran menyerahkan berita acara penilaian kepada Biro Renortala, seterusnya biro
Renortala menyerahkan berita acara penilaian kepada Menteri/Kepala Bappenas untuk disetujui.

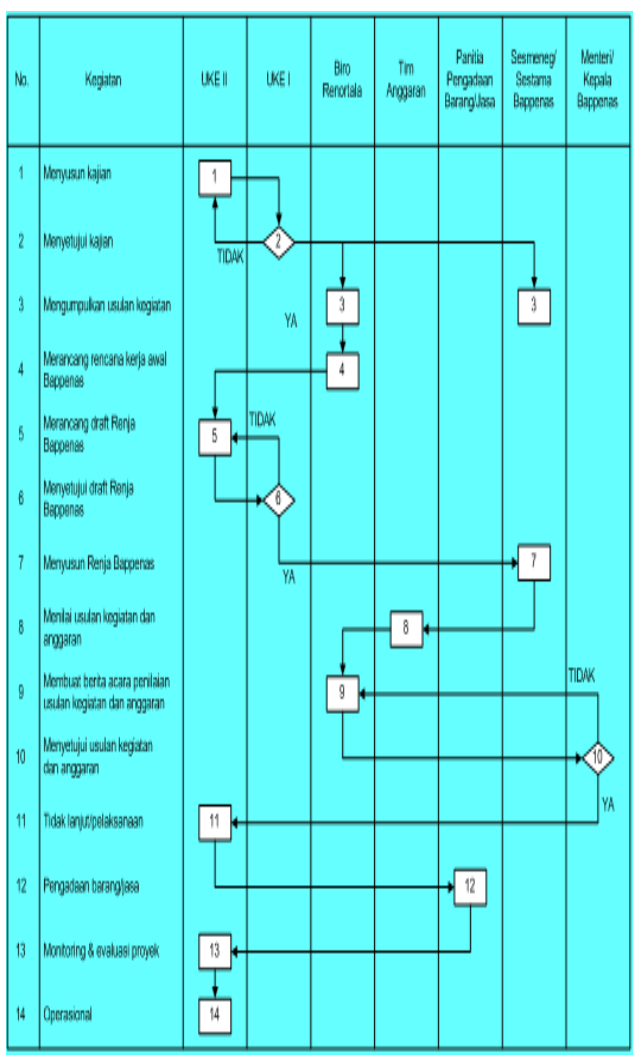

Gambar 9. Diagram Alir pengelolaan proyek Bappenas 


\subsubsection{Mekanisme Hubungan}

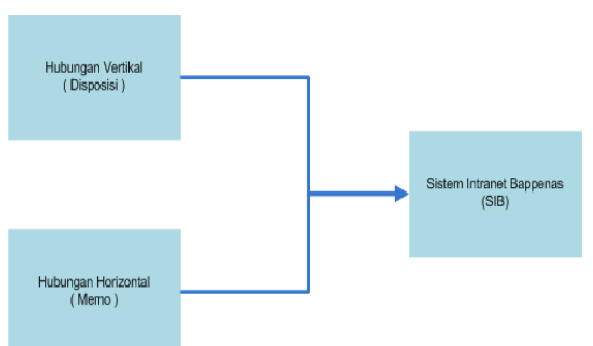

Gambar 10. Mekanisme hubungan

\subsubsection{Decission Making Sstructure Weill \& Ross (2004)}

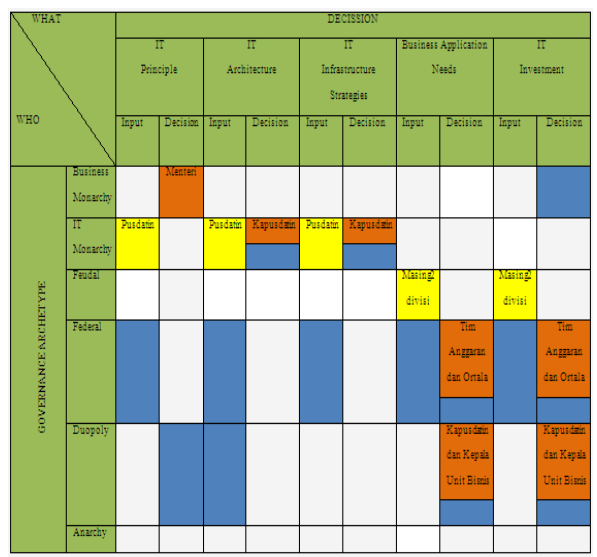

Gambar 11. Arrangement matrix

\subsubsection{Proses Keselarasan Weill \& Ross (2004)}

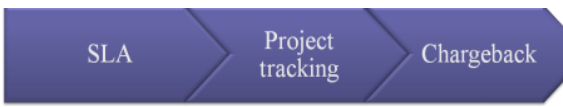

Gambar 12. Proses keselarasan

\subsubsection{Pendekatan Komunikasi Weill \& Ross (2004)}

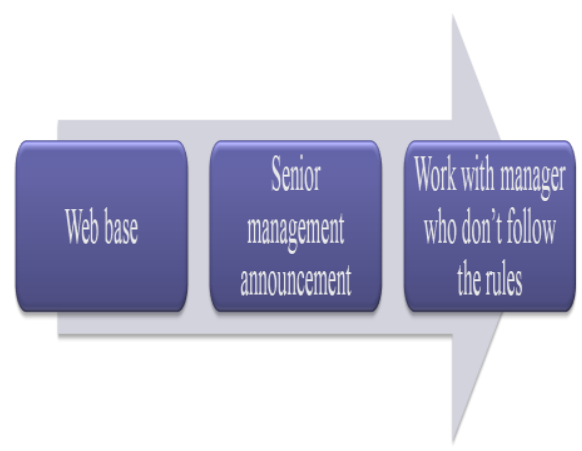

Gambar 13. Pendekatan komunikasi

\subsubsection{ITGI [1]}

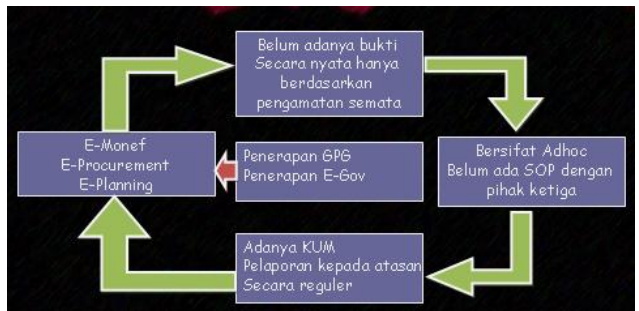

Gambar 14. ITGI [1]

\subsubsection{ICT Operation AS 8015 (2005)}

Implementasi pelaksanaan dari proyek TI yang sudah selesai dikerjakan diantaranya Sistem Intranet Bappenas, Digital Office, E-procurement.

\subsubsection{ICT Projects AS 8015 (Lanjutan)}

Proyek pengadaan investasi TI oleh masingmasing divisi biasanya masing divisi meminta investasi TI dalam hal database ex:E-planning, $E$ Monnef.

\subsubsection{Business Pressures AS 8015 (Lanjutan)}

- Keppres 80 tentang pengadaan barang dan jasa.

- Intruksi Presiden no 5 th 2004 percepatan pemberantasan korupsi.

4.3.11. Business Need AS 8015 (Lanjutan)

- Visi - Misi Presiden secara khusus dalam penerapan percepatan TI.

- Kepuasan para stakeholder diutamakan.

\subsubsection{Evaluasi Penggunaan ICT AS 8015 (Lanjutan)}

Belum terdapat evaluasi atau pengukuran secara resmi tentang penggunaan ICT, yang ada hanyalah pendekatan personal baik ke unit kerja maupun ke individu (user).

\subsubsection{Mengarahkan Penyusunan dan Iimplementasi Rencana dan Kebijakan AS 8015 (Lanjutan)}

Adanya kebijakan yang dilakukan TI terhadap divisi lain terkait masalah integrasi, setiap pengembangan TI di masing-masing divisi harus mengikuti standar yang diterapkan oleh Pusdatin.

\subsubsection{Memonitor Kepatuhan terhadap Kebijakan, dan Kinerja terhadap Target yang Direncanakan AS 8015 (Lanjutan)}

Pada Bappenas setiap periode memberikan laporan kepada Kepala Bappenas melalui Sekretaris Kementrian dan adanya Audit Internal oleh Inspektorat. 


\subsection{Permasalahan yang Terjadi di Bappenas}

\subsubsection{Penggunaan SIB}

Kubu 2 dan 3 menyebabkan hambatan dalam implementasi SIB. Akibatnya, SIB hanya efektif digunakan dalam unit kerja tertentu saja. Permasalahan ini akan menjadi semakin besar jika pihak yang berada di kubu 2 dan 3 merupakan pejabat Eselon I, sehingga jajaran direktorat yang berada di bawahnya tidak akan mengikuti atasannya. Hal ini mungkin saja disebabkan oleh kultur birokrat yang selalu mengikuti apa yang pimpinannya contohkan.

\subsubsection{Pengadaan Barang dan Jasa}

Pengadaan barang \& jasa telah diatur sepenuhnya dalam Keppres 80 Tahun 2003. Tentunya, investasi TI juga diharuskan menaati peraturan tersebut. Dalam siklus pengelolaan proyek Bappenas, perencanaan harus dilakukan setahun sebelumnya. Namun, ketika tiba masanya untuk mengeksekusi proyek tersebut, sebagian proyek TI akan mengalami keterlambatan. Hal ini disebabkan karena proses pengadaan yang seringkali memakan waktu yg cukup lama akibat ketatnya aturan dalam proses pengadaan tersebut. Panita pengadaan yg bertanggung jawab dalam proses pengadaan tidak berani untuk melanggar ketentuan yg sudah tertulis di Keppres 80 karena nantinya akan beresiko untuk diperiksa oleh KPK. Contohnya: hanya karena kurang lengkap dokumen administratifnya, pemenang tender terpaksa digugurkan. Akibatnya, harus diadakan tender ulang yang akan memakan waktu. Implementasi proyek TI menjadi terhambat sehingga waktu untuk pengembangannya akan menjadi sangat sempit. Hal ini akan mempengaruhi kualitas produk yang akan dihasilkan karena kemungkinan ada beberapa kebutuhan yang tidak sempat diimplementasikan karena keterbatasan waktu.

\subsubsection{Posisi Struktural Pusdatin}

Posisi struktural Pusdatin pada eselon dua membuat peran Pusdatin menjadi lebih terbatas walaupun pusdatin dapat lewat sesmen akan lebih mudah jika Pusdatin setingkat dengan eselon satu, dan hal ini juga yang mendasarkan bahwa Pusdatin kurang dilibatkan dalam proses investasi TI.

\subsubsection{Tidak Ada Pengelolaan Resiko}

Walaupun sudah ada SLA dengan pihak outsource terkait pengadaan komponen hardware, pengelolaan resiko harusnya menjadi suatu perhatian bagi Bappenas agar tingkat resiko seperti hacker, kebakaran dapat diminimalkan.

\subsubsection{Belum Adanya Bukti TI Telah Memberikan Nilai}

Belum adanya bukti kinerja TI belum memberikan nilai bagi Bappenas menjadi suatu permasalahan yang menyebabkan tata kelola TI pada Bappenas belum dapat diukur sudah sejauh mana tata kelola TI telah dilakukan sehingga dalam pelaksanaannya Pusdatin hanya bersifat "adhoc".

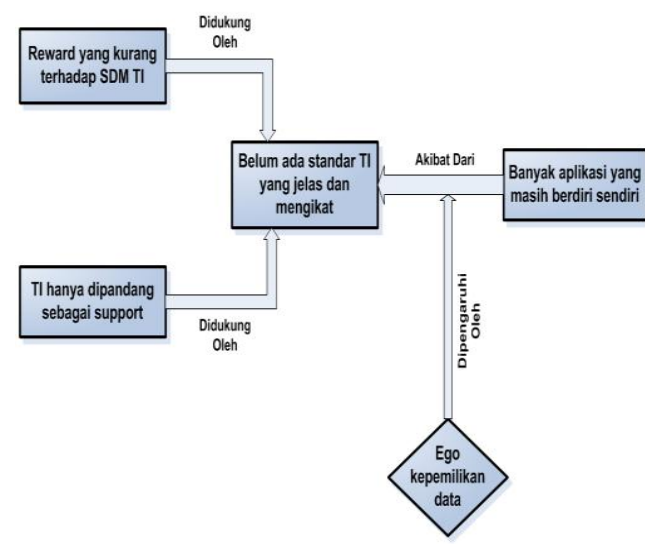

Gambar 15. Permasalahan pada Bappenas

\subsection{Solusi yang Ada di Bappenas}

\subsubsection{Sistem Intranet Bappenas}

Cara yg harus ditempuh agar seluruh pegawai Bappenas menggunakan SIB adalah dengan campur tangan Menteri PPN/Kepala Bappenas. Himbauan Sekretaris Menteri Bappenas saja tidak akan ampuh untuk mendorong penggunaan SIB karena para Deputi secara struktur sejajar dengan Sesmen. Menteri harus memerintahkan secara tertulis dan menggunakan SIB agar seluruh pegawai patuh. Namun, agar Menteri mau menggunakannya, Pusdatin harus melakukan pendekatan melalui Sesmen terlebih dahulu. Setelah itu, Sesmen dengan pendekatan personalnya, "membujuk" menteri untuk menggunakannya. Oleh karena itu, leadership sangat penting dalam penerapan TI di Bappenas.

\subsubsection{Solusi Keppres 80}

Ada dua cara untuk mengatasi permasalahan pengadaan barang dan jasa tersebut:

1. Membagi proyek ke dalam beberapa bagian dengan harapan seluruh kebutuhan dapat dipenuhi dengan baik.

2. Melakukan negosiasi dengan pemenang tender untuk tetap melanjutkan pengembangannya walaupun secara tertulis, 
kontraknya selesai pada akhir tahun. Hal ini dimasukkan dalam kegiatan maintenance.

\subsection{Solusi Menggunakan COBIT}

Untuk mendukung keputusan-keputusan TI serta mekanisme-mekanisme organisasi yang telah dianalisa sebelumnya diatas, maka ditentukan proses-proses TI untuk merincikan lebih jauh proses-proses yang harus dilakukan dalam mekanisme tersebut. Untuk memastikan keselarasan dengan tujuan organisasi, pengelolaan proses-proses tersebut ditekankan pada pencapaian target perilaku atau tujuan TI yang utama, yaitu:

1. Penyediaan dan pengembangan prasarana Teknologi Informasi dan Komuikasi (TIK);

2. Pengumpulan dan pengelolaan dokumen, arsip, kepustakaan, data, dan informasi; dan

3. Pengembangan jaringan informasi dan perpustakaan.

Berikut ini merupakan proses-proses TI yang harus dilakukan dan dikelola oleh pusdatinrenbang Bappenas berhubungan dengan tugasnya dalam memberikan layanan TI, dapat dikelompokkan berdasarkan domain:

- Plan \&Organise, seperti proses-proses:

PO1 Pendefinisian Rencana Strategis TI.

PO2 Pendefinisian Arsitektur Informasi.

PO3 Menentukan arah teknologi.

PO4 Pendefinisian Proses TI, Organisasi dan

Relasi di dalamnya.

PO5 Manajemen Investasi TI.

PO6 Komunikasi Tujuan Manajemen dan arahannya.

PO7 Manajemen sumber daya manusia TI.

PO9 Menaksir dan Mengelola resiko TI.

PO10 Mengelola proyek.

- Acquire \&Implement, seperti proses-proses:

AI1 Identifikasi Solusi yang otomatis.

AI3 Pengadaan dan Pemeliharaan Teknologi Infrastruktur.

AI4 Mengaktifkan Operasi dan penggunaannya.

AI5 Pengadaan Sumber Daya TI.

- Deliver \& Support

DS1 Pendefinisian dan Mengelola Tingkat Layanan.

DS2 Mengelola Kerja Sama dengan Pihak Ketiga.

DS3 Mengelola Kinerja pekerjaan dan Kapasitas pekerjaan.

DS7 Mendidik dan Melatih pemakai.

DS10 Mengelola Masalah.

DS11 Mengelola Data.

DS13 Mengelola Operasi.

- Monitoring \& Evaluate

ME1 Monitor dan Evaluasi kinerja TI.
ME4 Mengadakan suatu Tata Kelola TI.

Dari seluruh proses-proses TI yang didapat dapat ditentukan pada level berapa Bappenas berada tingkat kematangan tata kelola TI-nya, yang selanjutnya dapat ditentukan kemana target maturitas yang akan dicapai oleh Bappenas. berikut ini merupakan level kematangan tata kelola TI dari masing-masing prosesnya.

Berdasarkan hasil assessment yang dilakukan (Tabel 6), diperoleh tingkat kematangan TI pada Bappenas yaitu 2,247.

Dari Gambar 16 dapat diambil kesimpulan bahwa Bappenas berada pada level 2 tingkat kematangan tata kelola TI nya. Hal ini menunjukan bahwa Bappenas sebetulnya sudah mengerti bahwa proses-proses TI tersebut sangat penting untuk dilaksanakan namun pelaksanaanya masih banyak yang tidak terdokumentasi.

Tabel 6. Assessment Tingkat kematangan tata kelola TI

\begin{tabular}{|c|l|c|}
\hline ME1.4 & $\begin{array}{l}\text { Secara periode mereview kinerja apakah } \\
\text { sudah mendekati target atau belum }\end{array}$ & 4 \\
\hline ME1.5 & Pelaporan kepada Board and executive & 4 \\
\hline ME1.6 & $\begin{array}{l}\text { Melakukan perbaikan atas semua yang } \\
\text { telah dilakukan (kinerja, pelaporan yang } \\
\text { salah) }\end{array}$ & 4 \\
\hline ME4 & Mengadakan suatu Tata Kelola TI & 1.3 \\
\hline ME4.1 & $\begin{array}{l}\text { Membentuk suatu kerangka kerja tata } \\
\text { kelola TI }\end{array}$ & 0 \\
\hline ME4.2 & $\begin{array}{l}\text { Adanya keselarasan antara TI dan Bisnis } \\
\text { contoh:SLA }\end{array}$ & 2 \\
\hline ME4.3 & TI telah memberikan nilai bagi bisnis & 1 \\
\hline ME4.4 & Adanya pengelolaan sumber daya TI & 2 \\
\hline ME4.5 & Adanya suatu pengelolaan resiko & 1 \\
\hline ME4.6 & Adanya suatu ukuran dari kinerja yang ada & 1 \\
\hline ME4.7 & Adanya suatu kontrol secara independent & 2 \\
\hline \multicolumn{2}{|c|}{ Total Score: 49,44 / 22 =2,247 } \\
\hline
\end{tabular}

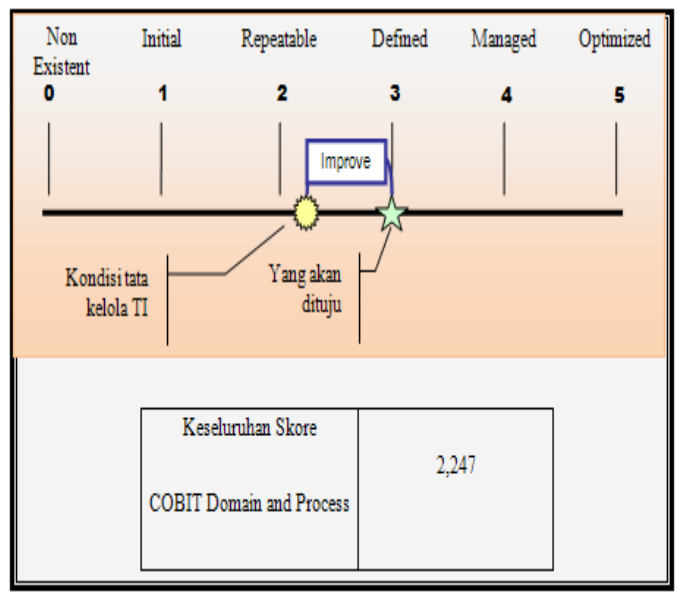

Gambar 16. Tingkat kematangan tata kelola TI Bappenas 
4.7. Usulan atas Proses Tata Kelola TI yang Ada

Melihat kondisi tata kelola TI yang ada maka dapat diberikan usulan pada Tabel 7 atas prosesproses TI yang masih berada pada tingkat kematangan tata kelola TI yang rendah berikut ini merupakan usulan atas proses-poses tata kelola TI yang rendah.

Tabel 7. Usulan atas proses-proses tata kelola TI

\begin{tabular}{|c|c|c|c|}
\hline $\begin{array}{l}\text { Mendidik } \\
\text { dan Melatih } \\
\text { pemakai }\end{array}$ & DS7 & $\begin{array}{l}\text { 3 Define } \\
\text { Process: } \\
\text {-Program } \\
\text { edukasi dan } \\
\text { pelatihan telah } \\
\text { melembaga, } \\
\text { dikomunikasika } \\
\text { n serta sudah } \\
\text { terstandardisasi } \\
\text { dan } \\
\text { terdokumentasi } \\
\text { kan } \\
\text {-Adanya } \\
\text { pelatihan formal } \\
\text { bagi pegawai } \\
\text { dalam hal etos } \\
\text { kerja, security } \\
\text { awareness, dan } \\
\text { langkah- } \\
\text { langkah } \\
\text { security. }\end{array}$ & $\begin{array}{l}\text {-Menyediakan } \\
\text { suatu dokumentasi } \\
\text { kebutuhan akan } \\
\text { pelatihan. } \\
\text {-Menyediakan } \\
\text { suatu program } \\
\text { edukasi dan } \\
\text { pelatihan yang } \\
\text { menyeluruh } \\
\text {-Membuat } \\
\text { kebijakan } \\
\text { organisasi yang } \\
\text { mensyaratkan } \\
\text { bahwa seluruh } \\
\text { pegawai } \\
\text { mendapatkan } \\
\text { pelatihan security } \\
\text { menyangkut etika, } \\
\text { tata cara security } \\
\text { dan ijin } \\
\text { penggunaan } \\
\text { sumber daya TI }\end{array}$ \\
\hline $\begin{array}{l}\text { Mengelola } \\
\text { Masalah }\end{array}$ & DS10 & $\begin{array}{l}\text { 3 Define } \\
\text { Process: } \\
\text {-Adanya suatu } \\
\text { tracking } \\
\text { masalah agar } \\
\text { dapat diberikan } \\
\text { suatu solusi } \\
\text {-Pemecahan } \\
\text { problem yang } \\
\text { standar }\end{array}$ & $\begin{array}{l}\text { - } \\
\text { Mengimplementas } \\
\text { ikan proses untuk } \\
\text { melaporkan } \\
\text { masalah yang } \\
\text { telah didefinisikan } \\
\text {-Membuat suatu } \\
\text { prosedur dalam } \\
\text { penanganan } \\
\text { masalah }\end{array}$ \\
\hline $\begin{array}{l}\text { Mengadakan } \\
\text { suatu Tata } \\
\text { Kelola TI }\end{array}$ & ME4 & $\begin{array}{l}\text { 3 Define } \\
\text { Process: } \\
\text {-Pengertian atas } \\
\text { kebutuhan tata } \\
\text { kelola TI dan } \\
\text { mengkomunikas } \\
\text { ikannya } \\
\text {-Prosedur sudah } \\
\text { standar dan } \\
\text { terdokumentasi }\end{array}$ & $\begin{array}{l}\text {-Membentuk suatu } \\
\text { kerangka kerja tata } \\
\text { kelola TI } \\
\text {-Menciptakan } \\
\text { keselarasan antara } \\
\text { TI dan Bisnis }\end{array}$ \\
\hline
\end{tabular}

\subsection{Faktor Pendukung dan Faktor Penghambat}

Setelah pembahasan di atas dapat dilihat bahwa posisi struktural Bappenas merupakan suatu faktor penghambat mengapa invetasi TI berjalan kurang baik, selain itu keinginan masing-masing untuk mengembangkan TI-nya dirasakan menjadi suatu masalah ketika Pusdatinrenbang ingin mengintegrasikannya, Keppres 80 yang dibuat sendiri oleh Bappenas pun ternyata menjadi permasalahan ketika peraturan yang ada membuat waktu menjadi sempit dan tidak sedikit membuat investasi yang dilakukan menjadi kurang baik, semua tentu berdasarkan kurangnya pemahaman orang-orang bisnis akan pentingnya suatu investasi TI.

Faktor-faktor yang menjadi pendukungnya adalah sudah mulai tumbuh rasa keinginan dari para pimpinan divisi lain setelah merasakan manfaat yang diberikan TI. Penerapan Good Public Governance pun secara tidak langsung mendorong Bappenas untuk meningkatkan tata kelola TI-nya. Gambar 17 merupakan faktor pendukung dan penghambat yang ada pada Bappenas.

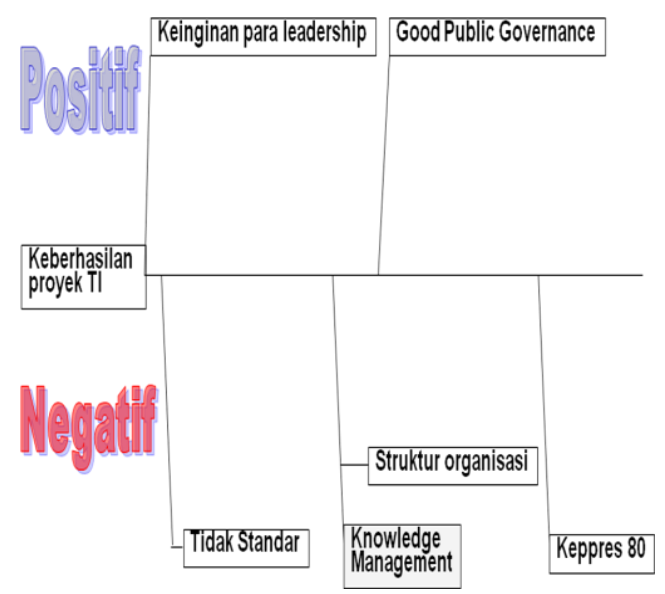

Gambar 17. Faktor penghambat dan pendukung pada Bappenas

\section{Penutup}

\subsection{Kesimpulan}

Penelitian ini merancang suatu model tata kelola TI pada Bappenas dari model yang dirancang kemudian dilakukan pemetaan bagaimana Badan Perencanaan Pembangunan Nasional (Bappenas) dapat mengimplementasikan tata kelola TI menggunakan campuran model diantaranya Peterson, Weill \& Ross, ITGI, dan AS 8015, kemudian dari model-model tersebut dapat diketahui permasalahan yang ada dalam proses TInya kemudian dilakukan solusinya menggunakan COBIT. Selain itu menurut penulis tata kelola TI pada Bappenas kurang mendapat perhatian dengan baik, dikarenakan masing-masing unit kerja/bagian sudah melakukan pengembangan aplikasi dan database sesuai dengan kepentingannya. Sehingga jika ingin dibangun sistem yang terintegrasi membutuhkan biaya, waktu serta sumber daya 
lainnya yang tidak sedikit. Belum lagi untuk proses pengajuannya yang melibatkan pihak-pihak tertentu dan tidaklah mudah, namun Bappenas pun berencana untuk berbenah diri dalam tata kelola TI dan juga melakukan integrasi sistem tersebut pada tahun 2008.

Pusdatinrenbang pun dirasa kurang berperan aktif selama ini, sehingga jika ingin menerapkan tata kelola TI dengan baik, Bappenas harus dapat memberdayakan Pusdatinrenbang dengan lebih optimal.

Penulis berharap agar paper ini akan bermanfaat untuk penelitian berikutnya, dan sebagai pembanding tentang penerapan tata kelola TI di Indonesia pada umumnya dan di organisasi pemerintahan pada khususnya.

\subsection{Saran}

Dari pemetaan yang dilakukan, penulis mempunyai beberapa saran, diantaranya agar posisi divisi TI dapat setara dengan posisi direktur, sehingga akan lebih cepat dalam proses pengambilan keputusan dari proyek TI. Hal ini disebabkan begitu pentingnya TI pada Bappeas untuk mendukung proses bisnis yang ada. Selain itu penulis menyarankan adanya suatu pengukuran kinerja bagi TI, dan hasil yang telah dicapai terdokumentasi. Hal ini akan baik apabila direalisasikan di Bappenas agar Bappenas sebagai institusi perencana pemerintah yang ikut serta dalam program mempercepat penggunaan TI di Indonesia dapat meningkatkan kemampuan TI di organisasinya agar bisa berkoordinasi dengan departemen lainnya dengan suatu mekanisme yang lebih baik.

\section{REFERENSI}

[1] IT Governance Institute, www.itgi.org, 2003.

[2] Van Grembergen, Wim, et al, Structures, Processes and Relational Mechanisms for IT Governance" in Strategies for Information Technology Governance, Idea Group Publishing , 2004.

[3] Weill, P. and Vitale, M., "What IT infrastructural capabilities are needed to implement e-business models", MIS Quarterly Executive, 1(1): 17-34, 2002.

[4] Peterson, R.R., "Configurations and coordination for global information governance: Complex designs in a transnational European context", Proceedings of the 34th HICSS Conference, Hawaii, 2001.

[5] Sambamurthy, V. and Zmud, R.W., "Research commentary. The organizing logic for an enterprise's IT activities in the digital era: A prognosis of practice and a call for research, Information Systems Research", 11(2): 105-114, 2000.

[6] Sambamurthy V. and Zmud R.W, "Arrangements for Information Technology Governance: a theory of multiple contingencies", MIS Quarterly, 23(2): 261290, 1999.

[7] Luftman, J., Competing in the Information Age: Practical Applications of the Strategic Alignment Model, New York: Oxford University Press, 1996.

[8] Brown, C.V. and Magill, S.L., "Alignment of the IS function with the enterprise: Toward a model of antecedents", MIS Quarterly, 8(4):371-403, 1994. 